\title{
The assessment of distances of intramuscular injection location from some landmarks in the students of Muğla School of Health Sciences
}

\author{
Intramusküler Enjeksiyon yerlerinin değerlendirilmesi \\ Fatih Esad Topal*, Birdal Yıldırım \\ Department of Emergency Medicine (Assist. Prof. F. E. Topal, MD), İzmir Katip Çelebi \\ University School of Medicine, TR-35230 İzmir, Emergency Service Unit (B. Yıldırım, MD), \\ Mugla State Hospital, TR-48200 Muğla
}

\begin{abstract}
Aim. This subject is a confusing matter for intramuscular injection administrators in clinical practice. The correct assessment of this situation is important for probable complications. There isn't any research in the literature that assesses the distances of the injection area to some landmarks. This study was carried out to determine these regions more accurately.Introduction.Intramuscular injection is a commonplace nursing procedure. Although considered a basic technique, it is far from innocuous. Gluteal region muscles are the most commonly used region in the practice and the necessary precautions must be taken. Method. A total of 216 male and female students, from University of Muğla School of Health Sciences, Nursing and Physiotherapy and Rehabilitation Departments were randomly selected and included to the study. Results. In this study we found that intramuscular injection location in males is $1.87 \pm 0.63 \mathrm{~cm}$ and in females $2.28 \pm 1.01 \mathrm{~cm}$ from the upper point. Conclusion. The research base for intramuscular injection site is limited. We think that these distances will be very valuable in clinical practice in the patient population consisting of 17-29 years of age and who have normal body mass index. This study will be a norm for patients who have a normal body mass index.
\end{abstract}

Keywords: Intramuscular injection, distance, injection site, body mass index, nursing, clinical practice, dorsogluteal site

\section{Özet}

Amaç. Bu çalışma klinik uygulamada kas içi enjeksiyon uygulayıcıları için kafa karıştırcı bir konudur. $\mathrm{Bu}$ durumun doğru değerlendirilmesi muhtemel komplikasyonlar için önemlidir. Enjeksiyon bölgesinin mesafesini değerlendiren literatürde herhangi bir araştırma yoktur.bu çalışma bu bölgeleri daha doğru bir şekilde belirlemek için gerçekleştirildi. İntarmusküler enjeksiyon yaygın bir hemşirelik uygulamasıdır. Temel bir teknik olarak düşünülmesine rağmen zarar vermektedir. Gluteal bölge kasları pratikte en yaygın kullanılan bölgedir ve gerekli tedbirler alınmalıdır. Yöntem. Mugla Üniversitesi saglık yüksek okulunun hemşirelik, fizyoterapi ve rehabilitasyon bölümünden kadın ve erkek toplam 216 öğrenci rastgele seçildi ve çalışmaya dahil edildi. Bulgular. $\mathrm{Bu}$ çalışmada intramusküler enjeksiyonun bayanlarda en üst noktadan 2,28 $\pm 1,01$ $\mathrm{cm}$ ve erkeklerde $1,87 \pm 0,63 \mathrm{~cm}$ aşagısı olduğunu bulduk. Sonuç. Bu araştırma intramusküler enjeksiyon yeri için sınırlı bir çalışmadır. Bu mesafelerin normal vücut indeksine sahip ve 17-29 yaş arası hasta populasyonunda klinik pratikte çok değişken olacağını düşündük. Bu çalışma normal vücut kitle endeksine sahip hastalar için bir norm olacak.

Anahtar sözcükler: İntramusküler enjeksiyon, mesafe, enjeksiyon yeri, vücut kitle endeksi, dorsogluteal bölge, hemşirelik

Geliş tarihi/Received: February 07, 2013; Kabul tarihi/Accepted: June 02, 2014

\section{*Corresponding author:}

Dr. Fatih Esad Topal, Acil Tıp Anabilim Dalı, İzmir Katip Çelebi Üniversitesi Tıp Fakültesi, TR35230 İzmir. E-mail: fatihetopal_18@hotmail.com 


\section{Introduction}

Drug administration techniques seem simple in the context of human health and treatment but it is a very important procedure. Drug administration in health disciplines, especially as a part of nurse education, is one of the basic concepts.

Intramuscular injection (IM) is one of the common methods of drug administration techniques. In different textbooks different administration techniques are explained about the location of IM injection [1-3]. This subject is confusing to IM injection administrators in clinical practice. The correct assessment of this situation is important for probable complications.

Intramuscular injection is a commonplace nursing procedure. Although considered a basic technique, it is far from innocuous [4]. Gluteal region muscles are the most commonly used region in the practice and the necessary precautions must be taken. Two injection techniques are currently recommended. The first, widely used in the United States, involves pinching the thigh muscle at the injection site to increase muscle mass and minimize the chance of striking bone [5]. The second, advised by the World Health Organization (WHO) [6], entails stretching the skin flat between the finger and thumb then injecting the needle at a $90^{\circ}$ angle (WHO). Such guidelines have not been offered for intramuscular delivery in adults.

IM is one of the common methods of drug administration techniques. In different textbooks different administration techniques are explained about the location of IM injection. IM injection is done in two locations in the gluteal region. These are dorsal gluteal region and ventrogluteal region [1-4]. In more recent years, authors have specified that the injection be located $5-7.5 \mathrm{~cm}$ below the crest of the ilium [7, 8].

We think that these distances will be very valuable in clinical practice in the patient population consisting of 17-29 years of age and who have normal body mass index. As now there isn't a morphometrical scale for determining IM injection location. For this reason this study will be a norm for patients who have a normal body mass index. There is not enough literature that evaluates parenteral drug administration regions. This study was done to determine these regions more accurately.

\section{Material and methods}

Intramuscular injection (IM) is one of the common methods of drug administration techniques. In different textbooks different administration techniques are explained about the location of IM injection. This is confusing to IM injection administrators in clinical practice. The aim of the study was to the correct assessment of this situation is important for probable complications.

This descriptive study was carried out between February 2008 and March 2008.

The study was conducted in the province of Mugla, Turkey in 2008. Participants were recruited from the Mugla School of Health Sciences, and 216 healthy adults were enrolled (148 woman, 68 men; range: 17-29 years. A total of 216 1, 2, 3 and 4th term class male and female students, from Mugla University, Mugla School of Health Sciences, Nursing and Physiotherapy and Rehabilitation Department were randomly selected and included to the study.

Data were collected in the Muğla School of Health Sciences, and following measurements were performed: The body height and weight of the participants were measured. The intramuscular injection location and the distances of this point to some landmarks were determined. Intramuscular injection location in dorsogluteal region was evaluated. 
Many authors suggest an alternative that involves palpation of the posterior superior iliac spine and greater trocanter of the femur $[3,9,10]$. An imaginary diagonal line is drawn between these two landmarks and the point is given above and lateral to the midpoint of the line.

Ethical considerations: All of the subjects who included in the study were informed of the study and we got their written consent. At the same time the official permissions were taken from the university.

Body mass index was calculated as weight $(\mathrm{kg})$ divided by height $\left(\mathrm{m}^{2}\right)$, and the measurement was analyzed separately for male and female participants and statistical analysis was done according to age, height, BMI and weight.

Data normality was assessed using Shapiro-Wilk's test. Variance homogeneity is tested using Levene's test. Comparisons between groups were performed using two-sided independent samples $t$ test. Correlation analysis were applied using Pearson correlation test. Values are expressed as mean and standard deviation. Analysis were performed using R 3.0.2 software (www.r-project.org) by considering a p value less than 5\% as statistically significant.

\section{Results}

The body height, weight, upper point, middle and transverse points of 216 participants according to gender, age, height and weight is given in (Table 1,2). When the measured parameters were evaluated generally, the distances were as follows: Upper point; $2.15 \pm 0.92 \mathrm{~cm}$, middle point $13.1 \pm 1.42 \mathrm{~cm}$, transverse point $14.22 \pm 1.71 \mathrm{~cm}$ (Table 1).

In this study we found that IM injection location in males is $1.87 \pm 0.63 \mathrm{~cm}$ and in females $2.28 \pm 1.01 \mathrm{~cm}$ from the upper point (Table 2). There was statistically significant difference between male and female students in height, weight, upper, middle and transverse points $(\mathrm{p}<0.05)$, there wasn't any statistically significant difference in other parameters $(\mathrm{p}>0.05)($ Table 2).

When upper, middle and transverse point distances were evaluated according to age, the distances didn't change $(p>0.05)$. When upper, middle and transverse point distances were evaluated according to height, the distances didn't change ( $p>0.05)$. When the mean average, standard deviation and minimum and maximum values of measured parameters were evaluated according to weight, the middle point value increased with the increments in weight $(\mathrm{p}<0.05)$. There was a strong correlation between middle point and transverse point. There was correlation between "BMI and middle point" and between "BMI and transverse point", no correlation between upper point and any other parameter could be detected (Table 3).

Table 1. Mean averages, standard deviations and error values of parameters measured in male and female participants.

\begin{tabular}{llllll}
\hline Parameters & Minimum & Maximum & Mean average & St. error & St. deviation \\
\hline Height & 150 & 188 & 168.73 & 0.55 & 8.21 \\
Age & 16 & 29 & 20.40 & 0.13 & 1.92 \\
BMI & 15 & 27 & 20.84 & 0.16 & 2.38 \\
Weight & 43 & 95 & 59.67 & 0.71 & 10.47 \\
Upper Point & 0.80 & 11.30 & 2.15 & 0.06 & 0.92 \\
Middle & 4.30 & 17.20 & 13.10 & 0.09 & 1.42 \\
Transverse & 1.20 & 18.70 & 14.22 & 0.11 & 1.71 \\
\hline
\end{tabular}


Table 2. The comparisons of measured parameters in male and female subjects (Student $t$ test).

\begin{tabular}{|c|c|c|c|c|c|c|}
\hline & Male (n: 68) & & Female (n: 148) & & & \\
\hline Parameters & $\begin{array}{l}\text { Mean } \pm \text { standard } \\
\text { deviation }\end{array}$ & $\begin{array}{l}\text { Standard } \\
\text { error }\end{array}$ & $\begin{array}{l}\text { Mean } \pm \text { standard } \\
\text { deviation }\end{array}$ & $\begin{array}{l}\text { Standard } \\
\text { error }\end{array}$ & $\mathbf{p}$ & $\mathbf{t}$ \\
\hline Height & $177.83 \pm 5.47$ & 0.66 & $164.54 \pm 5.39$ & 0.44 & 0.000 & 13.9 \\
\hline Age & $20.89 \pm 2.33$ & 0.28 & $20.18 \pm 9.15$ & 0.75 & 0.100 & 1.62 \\
\hline Weight & $70.10 \pm 10.49$ & 1.27 & $54.49 \pm 7.47$ & 0.61 & 0.000 & 11.19 \\
\hline BMI & $22.1 \pm 2.6$ & 0.32 & $20.2 \pm 1.9$ & 0.16 & 0.180 & 2.39 \\
\hline Upper point & $1.87 \pm 0.63$ & 0.07 & $2.28 \pm 1.01$ & 0.08 & 0.004 & -2.90 \\
\hline Middle point & $12.98 \pm 1.25$ & 0.15 & $13.15 \pm 1.50$ & 0.12 & 0.005 & -1.95 \\
\hline Transverse point & $13.52 * \pm 1.20$ & 0.14 & $14.55 \pm 1.82$ & 0.15 & 0.000 & -5.11 \\
\hline
\end{tabular}

Table 3. The correlation coefficients between measured parameters.

\begin{tabular}{lllllll}
\hline & Height & Age & Weight & Upper Point & Middle Point & Transverse oint \\
\hline Height-r & 1 & 0.121 & $0.758^{* *}$ & -0.030 & $0.146^{*}$ & -0.110 \\
$\mathrm{p}$ & - & 0.075 & 0.000 & 0.664 & 0.031 & 0.108 \\
\hline Age-r & 0.121 & 1 & $0.197 * *$ & -0.026 & 0.096 & 0.090 \\
$\mathrm{P}$ & 0.075 & - & 0.004 & 0.705 & 0.162 & 0.186 \\
\hline Weight-r & $0.758^{* *}$ & $0.197 * *$ & 1 & -0.058 & 0.380 & 0.108 \\
$\mathrm{P}$ & 0.000 & 0.004 & - & 0.398 & 0.000 & 0.113 \\
\hline BMI-r & $0.273^{* *}$ & $0.188^{* *}$ & $0.830^{* *}$ & 0.061 & $0.449^{* *}$ & $0.259^{* *}$ \\
$\mathrm{p}$ & 0.000 & 0.000 & 0.000 & 0.56 & 0.000 & 0.000 \\
\hline Upper-r & -0.030 & -0.026 & 0.058 & 1 & 0.078 & 0.130 \\
Point-p & 0.664 & 0.705 & 0.398 & - & 0.253 & 0.057 \\
\hline Middle-r & $0.146^{*}$ & 0.096 & $0.380^{* *}$ & 0.078 & 1 & $0.749^{* *}$ \\
Point-p & 0.031 & 0.162 & 0.000 & 0.253 & - & 0.000 \\
\hline Transverse-r & 0.110 & 0.090 & 0.108 & 0.130 & $0.749 * *$ & 1 \\
Point-p & 0.108 & 0.186 & 0.113 & 0.57 & 0.000 & - \\
\hline \multicolumn{7}{c}{$*: \mathrm{p}<0.05$ significant, **: $\mathrm{p}<0.001$ high level significant. } \\
\hline
\end{tabular}

\section{Discussion}

Drug administration sites can be divided into two main groups according to the target of drug and the intent of drug: Local administration sites and systemic administration sites.

If the target of the drug on the surface of the body, the drug can be administered locally. If a systemic effect is wanted or a local effect is needed but the drug cannot be administered locally, as often is the case, the drug can be injected into a suitable tissue (eg. intramuscular or subcutaneous) or administrated to mucosal spaces and absorbed from here.

Drug administration is one of the legal responsibilities of nurses. "Errors in Drug Administration" can be defined as faulty applications due to erroneous behaviors in the principles of correct drug administration. In 20011.200 patients died because of faulty drug administration in United Kingdom. This finding represented a 500\% increase in the last ten years $[11,12]$. In United States of America (USA), errors in drug administration was detected in 770 000-2 000000 patients admitted to hospitals [13].

The principles of parenteral drug administration are universal. Administrations conditions, technical resource standards and care quality create differences in practices. In addition to the contribution it makes to health of the patient, although it is rare, there can also be adverse effects. The content of the drug, inappropriate administration site, mistakes in dilution of the drug, faulty dosages, administration of the drug against contraindications unsterile conditions, inappropriate equipment usage, health professionals technical knowledge and skill and the characteristics of patient are factors that effect the formation of adverse effects. 
For these reasons the health professionals should achieve adequate skill and correct information level in the administration of drugs.

The four most commonly referenced IM injection sites for adults in the current literature are the dorsogluteal, ventrogluteal, vastus lateralis and deltoid, but it is apparent that some have greater advantage than others.

The dorsogluteal site is located in the superior lateral aspect of the gluteal muscles. Some authors consider the target muscle to be the gluteus medius $[14,15]$, others refer to it as the gluteus maximus [16, 17], and still others as the thick gluteal muscles of the buttocks, suggesting both muscles are appropriate [18]. Such inconsistency causes confusion in locating the best site. Historically, the dorsogluteal site was the main site for IM injections [19].

Many authors suggest an alternative that involves palpation of the posterior superior iliac spine and greater trocanter of the femur [3, 9] (e.g. Kozier \& Erb 1989, Craven \& Hirnle 2003). An imaginary diagonal line is drawn between these two landmarks and the injection is given above and lateral to the midpoint of the line.

Traditionally, the dorsogluteal site was located by marking the buttock into quadrants, with the vertical line extending from the iliac crest to the gluteal fold and the intersecting horizontal line extending from the medial fold to the lateral aspect of the buttock. The injection was given in the upper outer quadrant. In more recent years, authors have specified that the injection be located $5-7,5 \mathrm{~cm}$ below the crest of the ilium [7, 8]. Some authors recommend that the upper outer quadrant be divided again into quadrants and that the injection be given in the upper outer quadrant of the upper outer quadrant [20, 21], thus distancing the injection from the sciatic nerve. However, the quadrant method has been criticized for lacking precision [2, 3].

The sciatic nerve, the broadest nerve of the body which pass through the inferior aspect of the buttocks and descend into the thighs, supply skin and muscles in the legs and feet [22]. These are the most vulnerable peripheral nerves due to IM injection because of their large size and because the buttock area is a common injection site [23-29].

In addition to the complications arising from injecting the drug to the sciatic nerve, other complications like abcess, necrosis, and skin or nerve damage, chronic pain can be seen. Because injecting the drug directly to the nerve is almost impossible, nerve damage more commonly occurs as a result of the leakage of the drug between tissues. In this conditions instead direct nerve injury, the nerve damage occurs due to the characteristics of the drug and accumulation of the drug in epineuronal level [30].

If the needle touches nerve a severe pain develops and the pain is generally felt along the route of the nerve. If the drug is injected to the nerve the neurological symptoms don't develop acutely, symptoms are seen according to the effect of the drug. Injections made very close to a peripheral nerve can cause a very important defect in the continuity of the nerve $[23,25,26,30]$.

50 patients who had sciatic nerve lesions which had developed after injections were followed long term. In $36 \%$ of the cases complete, in $24 \%$ of cases incomplete recovery was seen and in $40 \%$ of cases no recovery was observed [31]. These patients are usually treated conservatively and no surgical intervention is done. The patients are rested in neutral position in acute stage, later electrostimulation, opening of joint space and strengthening exercises is done and patients are followed by EMG [27]. The neurotoxic effects of the drugs can also cause sciatic nerve damage. 
To assess properly the target injection area and accurately locate landmarks and boundaries, the injection site must be completely exposed [15, 32]. Landmarks should be palpated, as visual calculations alone can result in an injection being placed outside the appropriate target area [17].

We think that these distances will be very valuable in clinical practice in the patient population consisting of 17-29 years of age and who have normal body mass index.

Study limitations: Our study has several limitations. Participants were relatively young and healthy, and their age and weight distributions may have been more limited than those of general population. Further research is needed to compare the differences in obese and cachectics individuals.

When the measured parameters were evaluated generally, the distances were as follows: Upper point; $2.15 \pm 0.92 \mathrm{~cm}$, middle point $13.1 \pm 1.42 \mathrm{~cm}$, transverse point $14.22 \pm 1.71 \mathrm{~cm}$. In this study we found that IM injection location in males is $1.87 \pm 0.63 \mathrm{~cm}$ and in females $2.28 \pm 1.01 \mathrm{~cm}$ from the upper point. We think that these distances will be very valuable in clinical practice in the patient population consisting of 17-29 years of age and who have normal body mass index. This study will be a norm for patients who have a normal body mass index.

Although IM injection is considered a basic skill, it must be treated with due diligence. To avoid complications nurses must know the anatomy, and advantages and disadvantages of injection sites, be able to accurately identify anatomic landmarks and site boundaries, know the particulars of injection technique, and administer the injection using careful technique.

There have been few studies carried out, and many that exist are dated or have methodological limitations or both. Guidelines for clinical practice based on sound and recent evidence are needed. In addition these results will be a reference when the injection distances in cachectics (body mass index under 18.5) and obese patients are evaluated in future studies.

Acknowledgement; we wish to thank all the people all the people who so willingly participated in this study.

Author contributions; FB, NA, LA, BY and AB were responsible for the study conception and design and the $\mathrm{FB}, \mathrm{NA}, \mathrm{LA}$, and $\mathrm{BY}$ were responsible for the drafting of the manucript, FB, NA and $\mathrm{AB}$ performed the data collection and FB and NA performed the data analysis. LA and BY provided administrative support, NA made critical revisions to the paper, and provided statistical expertise, and supervised the study. What is already known about this topic? IM injection is done in two locations in the gluteal region. These are dorsal gluteal region and ventrogluteal region. In practice the most commonly used region is gluteal region muscles. The gluteal site can be less effective for intramuscular injections than other sites, such as deltoid. What this paper adds; this study will be a norm for patients who have a normal body mass index. We think that these distances will be very valuable in clinical practice in the patient population consisting of 17-29 years of age and who have normal body mass index. 


\section{References}

1. Potter PA, Perry AG. Intramusculer injections, sites. Fundamentals of nursing concepts, process and practice, fourth edition, missouri: Mosby Company1997; 828-35.

2. Perry AG. \& Potter PA. Clinical Nursing Skills and Techniques, 5th edn. Mosby, St Louis, MO 2002.

3. Kozier B, Erb G. Techniques in Clinical Nursing, 3rd edn. Addison-Wesley, Redwood City, CA. 1989.

4. Small SP. Preventing sciatic nerve injury from intramuscular injections: Literature review. Journal of Advanced Nursing 2004; 47: 287-96.

5. Bergeson PS, Singer SA, Kaplan AM. Intramuscular injections in children, Pediatrics 1982; 70: 944-8.

6. World Health Organization. Immunization in practice (a guide for health workers who give vaccines). 3. When and how to give vaccines. EPI/PHW/84/3 Rev. 1. Geneva, Switzerland: World Health Organization 1984.

7. DuGas BW, Knor ER. Nursing Foundaions: A Canadian Perspective. Appleton \& Lange, Scarborough, ON 1995.

8. Perry AG, Potter PA. Clinical Nursing Skills and Techniques, 4th edn. Mosby, St Louis, MO 1998.

9. Craven RF, Hirnle CJ. Fundamentals of Nursing: Human Health and Function, 4th edn. Lippincott Williams \& Wilkins, Philadelphia 2003.

10. Zaybak A, Güneş ÜY, Tamsel S, Khorshid L, Eşer İ. Does Obesity Prevent the Needle from Reaching Muscle in Intramuscular Injections? Journal of Advanced Nursing 2007; 58: 552-6.

11. Preston RM. Drug errors and patient safety: The need for a change in practice. $\mathrm{Br}$ J Nurs 2004; 13: 72-8.

12. Dimond B. Research shows administration of medicines needs attention. $\mathrm{Br} \mathrm{J}$ Nurs 2003; 12: 397.

13. Beyea S. Wake-up-call-standardization is crucial to eliminating medication errors. AORN J 2002; 75: 1010-3.

14. Monaghan JC. Procedures for your clinical practice. Patient Care 1990; 24: 14756.

15. Gilsenan I. Injections. Nursing Times 2000; 96: 43-4.

16. DuGas BW, Esson L, Ronaldson SE. Nursing Foundations: A Canadian Perspective, 2nd edn. Prentice Hall, Scarborough, ON 1999.

17. Harkreader H. Fundamentals of Nursing: Caring and Clinical Judgment. Saunders, Philadelphia 2000.

18. Kozier B, Erb G, Berman AJ, Burke K. Fundamentals of Nursing: Concepts, Process, and Practice, 6th edn. Prentice Hall Health, Upper Saddle River, NJ 2000

19. Ross-Kerr JC \& Wood MJ. Canadian Fundamentals of Nursing, 2nd edn. Mosby, Toronto 2001.

20. Campbell J. Injections. Professional Nurse 1995; 10: 455-8.

21. Kerr JR, Sirotnik M. Canadian Fundamentals of Nursing. Mosby, St Louis, MO 1997.

22. Williams PL, Bannister LH, Berry MM. Gray's Anatomy. Soames, R. W. Edn. 39th. Churchill Livingstone, London 1995; 1283-5.

23. Broadbent TR, Odom GL, Woodhall B. Peripheral nerve injuries from administration of penicillin: Report of four clinical cases. JAMA 1949; 140: 1008-10.

24. Clark K, Williams P, Willis W. Injection injuries of sciatic nerve. Clin Neurosurg 1970; 17: 111-25.

25. Coombes M, Clark W, Gregory C. Sciatic nerve injury in infants: Recognition and prevention of impairment resulting from intragluteal injections. JAMA 1960; 
173: $1336-8$

26. Kline DG. Diagnostic approach to individual nerve injuries. In: Wilkins R, Rengachary S. Neurosurgery. New York: McGraw-Hill 1996; 3125-46.

27. Huang Y, Yan Q, Lei W. Gluteal sciatic nerve injury and its treatment. Zhongguo Xiu Fu Chong Jian Wai Ke Za Zhi 2000; 14: 83-6.

28. Yuen EC, So YT Olney YK. Sciatic neuropathy: Clinical and prognostic features in 73 patients. Neurology 1994; 44: 1669-74.

29. Yuen EC, So YT, Olney RK. The electrophysiologic features of sciatic neuropathy in 100 patients. Muscle Nerve 1995; 18: 414-20.

30. Mayer M, Romain O. Sciatic paralysis after a buttock intramuscular injection in children: An ongoing risk factor. Arch Pediatr 2001; 8: 321-3.

31. Ahuja B. Post injection sciatic nerve injury. Indian. Pediatr 2003; 40: 368-9.

32. Nicoll LH. \& Hesby A. Intramuscular injection: An integrative research review and guideline for evidence-based practice. Applied Nursing Research 2002; 16, $149-62$. 